\title{
THE FACTORS AFFECTING PURCHASING DECISION THROUGH PEGIPEGI APPLICATION BY CUSTOMERS OF DIAN NUSWANTORO UNIVERSITY
}

\author{
Diana Aqmala $^{1^{*}}$, Febrianur Ibnu Fitroh Sukono Putra ${ }^{2}$, Dian Yustika Rini ${ }^{3}$ \\ ${ }^{1,2,3}$ Dian Nuswantoro University, St. Imam Bonjol No. 207, Pendrikan Kidul, Central Semarang, \\ Semarang City, Central Java, Indonesia 50131 \\ e-mails: ${ }^{1}$ diana.aqmala@gmail.com; ${ }^{2}$ fbr10@dsn.dinus.ac.id; ${ }^{3}$ yustika.dian20@gmail.com
}

Received January 18, 2021; accepted January 27, 2021; published January 29, 2021.

\begin{abstract}
Objective: This research aims to analyze the factors which influence online purchasing decisions through Pegipegi application. Research Design \& Methods: This research method is quantitative with 170 respondents which Dian Nuswantoro University students. The sampling technique is purposive sampling through questionnaires with Likert scale. The analytical technique is structural equation modeling (SEM). Findings: The finding results showed that 1) Electronic Word-of-mouth has significantly direct effect on purchase decision, 2) price perception has a significantly direct effect on purchase decision, 3) product quality has a significantly direct effect on purchase decisions, 4) brand awareness is able to mediate the effect of electronic word-of-mouth, price perception, and product quality on purchase decision. Implications \& Recommendations: This research has managerial implications for the marketing policies implemented by Pegipegi application to increase the customer awareness, so it will increase the customer desire immediately to buy the service. Contribution \& Value Added: This research provides the factors which companies need to consider in the marketing policy, so they can increase the market share among millennials customer and they can also increase the competitiveness of travel service companies in the industry.
\end{abstract}

Keywords: electronic word-of-mouth, price perception, product quality, purchase decision.

JEL codes: M13, M15, M31

Article type: research paper

\section{INTRODUCTION}

In this era globalization, business world has been developing very fast that competition among companies. Various businesses are present in this competition. Modern marketing also no longer refers to how the product can not only be sold to customers but also must be able to provide a price value for the products issued by the company. There have been many different kinds of efforts by the company to provide a choice of its products to customers, especially those who have something in common. The change from the traditional era to the digital era encourages people to become more real time, personal, and interactive. This change also affects the industrial sector to become more digital, especially for Indonesian millennials (Vijai \& Anitha, 2020). Future business transactions are predicted to move from shops to marketplaces (online) of websites that sell products or services online. The Internet is the latest online medium in modern information systems. The internet is becoming a popular electronic media used in business both in the service and sales fields. This term is called electronic commerce or ecommerce (Cummins, Peltier, Schibrowsky, \& Nill, 2014).

The intense competition in the tourism \& travel sector encourages agents to strive to improve service and convenience for customers. One of the most popular e-commerce services in travel and travel services is pegipegi, which provides web-based flight information and tickets and hotel services (Parmana, Fahmi, \& Nurrohmat, 2019). Customer decisions in purchasing a product require a process. 
The process of making a decision to buy a product starts from finding information, evaluating, identifying problems with several alternatives, which will then create a purchase decision and form postpurchase behavior. In making purchasing decisions, customers pay attention to brand awareness, which is the ability of customers to identify a brand in certain conditions by means of brand recognition and brand recall. Brand awareness is created through increasing brand familiarity by means of repeated exposure so that customers feel familiar with the brand (Putra, Budiantoro, Luxfiati, \& Widawati, 2020).

Responding to intense competition among travel companies, Pegipegi as a travel company reorganized its promotional activities in an effort to increase brand awareness and sales. One of the promotional activities by Pegipegi is to build lower prices for customers. Promotion is being intensified to communicate differentiation in various media. The Pegipegi application is an e-commerce company selling airline tickets and hotel services online. The Pegipegi application is one of e-commerce in travel sector that has not developed significantly.

Table 1. Comparison of Online Travel Service Application Services

\begin{tabular}{ccccc}
\hline No & Site & Ever Visited Site & Brand Awareness & Top of Mind \\
\hline 1. & Traveloka & 68.8 & 89.4 & 42.5 \\
2. & Tiket.com & 41.2 & 66.3 & 13.2 \\
3. & Agoda & 26.8 & 42.0 & 3.4 \\
4. & Wego & 17.0 & 32.8 & 1.8 \\
5. & Pegipegi & 17.5 & 34.5 & 1.3 \\
\hline Source : dailysocial.id, $(2020)$ & & &
\end{tabular}

It can be seen from the four comparisons that Pegipegi has a superior category in brand awareness and ever visited sites on the Wego site but is still under Traveloka, Tiket.com, and Agoda. However, when compared to Wego in top of mind, Pegipegi is still ranked lower and far behind the other three sites. Based on the above phenomenon, it shows that Pegipegi needs to fix the marketing policies implemented in order to increase competitiveness in the industry and expand the reach of market share (Putra et al., 2020). Several important factors to improve customer's purchasing decisions, Pegipegi made improvements including the use of Word-of-mouth (WOM), improving product quality, and positioning by building the perception of low prices. This research provides the factors which companies need to consider in the marketing policy, so they can increase the market share among millennials customer and they can also increase the competitiveness of travel service companies in the industry. Finally, this research aims to analyze the effect of EWOM, price perception, and product quality on brand awareness in order to increase customer purchase decision.

\section{LITERATURE REVIEW}

\section{Marketing}

Marketing is often seen as a process for creating, promoting and delivering products to customers as a part of business. Marketing is expected to be able to drive demand for products produced by the company (Kotler \& Keller, 2016). Marketing management is the direction or control of all marketing activities of a company or division of a company. In other words, marketing is the process of exchanging goods or services to meet the needs and desires of individuals and groups to produce mutually beneficial conditions. Marketing strategy (marketing strategy) is a design by the company to maximize the use of its resources to achieve marketing goals. The evaluation and selection of the target market is a group of people as the target of all the marketing company efforts. The influence of the target market on the level of costs and profits of sales of the company must be considered to determine the company's target market by designing and compiling the Marketing Mix. Marketing Mix is a collection of marketing tools that companies use to achieve marketing goals in target markets (Gichuru \& Limiri, 2017; Yasmin \& Islam, 2019).

\section{Purchasing Decision}

Basically, customer behavior is closely related to purchasing decisions. The influence of customer behavior is very large in the marketing activities of a company in purchasing decisions. This is because 
when a customer before and after purchasing a product, the company cannot detect the customer's thoughts. A purchasing decision is a decision-making process that includes what to buy or not. This purchasing decision resulted from the experience of previous activities (Fahrezzy, 2018).

In a purchase decision, there are five roles that a person can play. The five roles include:

1. initiator, the person who first becomes aware of an unmet need and proposes an idea to buy a certain goods or services,

2. influencer, namely someone who provides an opinion so that it can help with purchasing decisions,

3. decision maker, namely the customer who determines the purchase decision, whether it is a decision on what product to buy or how to buy,

4. buyers, namely people who make real purchases,

5. user, namely a person who uses or consumes the goods or services that have been purchased.

Customers making purchasing decisions do not just happen, but there is a process that can be described on the following Figure 1:



Figure 1. Customer Purchase Decision Process

From the Figure 1 above, it can be captured that:

1. Identifying Needs, called recognizing a need is the beginning of the process of purchasing a product. The trigger for a need must be identified by a marketer.

2. Information Search. It means, in the search for needs, someone will try to find more information about the desired product.

3. Alternative Evaluation is a process of suitability of selected alternative choices to meet needs

4. Purchasing Decision to buy is a process in the actual purchase. After doing the initial stage, the customer will make a decision.

5. Post Purchase Behavior. In this process, the behavior after the customer makes a purchase is influenced by customer satisfaction with a product purchased. Customers will be satisfied if the products purchased are what they expect, even marketers are targeted to exceed the standards of customer desires.

\section{Brand Awareness}

Brand Awareness describes the awareness of a brand as a determinant of the quality of an item. Raising awareness is a mechanism to expand the brand market. Brand awareness is the opening key to tapping into other elements. If brand awareness is considered very low, then this can be ascertained that the quality of a brand is certainly low (Latif, Islam, \& Noor, 2014). The role of brand awareness in brand equity depends on the level of attainment of customer awareness. The levels of brand awareness are divided into 4 levels, namely:

1. Unware of Brand, namely the lowest level of a brand where customers are not aware of the existence of a brand.

2. Brand Recognition: namely the minimum level of brand awareness known by their recognition, including using a list of images, a list of brands, or a brand stamp. A brand that enters a customer's memory is also known as brand recognition.

3. Brand Recall: Reflects any brands that customers can remember after mentioning the first mentioned brand. The brand will also be mentioned second, third and so on are brands that occupy brand recall in the minds of customers.

4. Top of Mind is the brand that is spontaneously on the customer's mind. In other words, the brand is the main brand of a variety of brands that are in the minds of customers. 


\section{Electronic Word-of-mouth (EWOM)}

The traditional word-of-mouth (WOM) has been shown to play an important role in the customer decision-making process by influencing customer choice. Basically, communication aims to provide customer information so that customers are aware of the existence of the product being offered. Wordof-Mouth as a process for customers to exchange information and opinions regarding products or services with others. However, along with the transition that occurred, especially in the field of technology and information, the concept of Word-of-Mouth developed and gave birth to a concept in accordance with the change itself, namely Electronic Word-of-mouth (e-WOM) Communication (Sulthana \& Vasantha, 2019). Electronic Word-of-mouth communication refers to positive or negative statements made by customers regarding product or company information that is available and accessible via the internet.

One type of Electronic Word-of-mouth that has an important role today is online reviews considered to provide important and reliable information. The presence of online reviews (OR) provides a breakthrough in the marketing world. This is related to the benefits of online reviews for customers, namely the use of blogs, search engines (browsers), virtual communication, social media, instant messenger and customer reviews to collect and disseminate product information. Adopting information from online reviews can be interpreted as a process by which people are deliberately involved in using information (Trinanda \& Sari, 2019). In the tourism industry, the term online review can be interpreted as an electronic version of traditional word-of-mouth, which consists of comments published by tourists regarding products, services and brands as a form of online reviews encouraging and spreading new word-of-mouth in the travel industry. Online customer reviews are an electronic version of word-ofmouth that is increasingly popular among customers around the world when a customer reads online reviews before making a purchase decision (Indiani, Rahyuda, Yasa, \& Sukaatmadja, 2015).

\section{Price Perception}

Price is very important for customers as a guide to measure the accuracy between the benefits of the product received and the sacrifices given in the form of money or other sacrifices. Many companies take various approaches to pricing based on the objectives to be achieved, namely increasing sales, expanding and / or maintaining market share, maintaining price stability, achieving maximum profit, and so on (Opusunju \& Ojeleye, 2017). The indicators for measuring price perception aim to stimulate the sensitivity of customers to buy because affordable prices are the expectations of customers before they make a purchase. Customers will look for products at affordable prices following their income. Therefore the company needs to know and understand the level of income that is in the market segments as its target (Putra et al., 2020).

\section{Product Quality}

Product quality is the ability of a product to carry out its function, including reliability, durability, reliability, ease of operation, and product improvement, as well as other valuable attributes to meet customer needs and expectations when purchasing the product (Musi, 2017). In addition, product quality is also defined as the overall characteristics of a product as well as the ability to provide services to satisfy stated or implied needs. Product quality reflects the product's ability to carry out its duties including durability, reliability, progress, strength, ease of packaging, product separation, and so on (Sitanggang, Sinulingga, \& Fachruddin, 2019).

The marketed product is a good weapon in winning the competition if it meets high quality, with other words in the expression "quality first" or quality as the main thing. Quality is the level of quality expected and variety control to meet customer needs. Thus, quality is a key success factor for an organization or company where quality is "the best guarantee for customer loyalty, the strongest defense against competition and the only way to progress and lasting income. Product quality is something that needs the main attention of the company / manufacturer, considering that the quality of a product is closely related to customer satisfaction issues (Wijaya, 2017). The close relationship between product quality and customer purchasing decisions requires companies to carry out quality management so as to create high customer satisfaction. Quality management is a collection of activities related to certain 
qualities. Product quality management includes all activities including the management function as a determinant of quality policy, goals and responsibilities, as well as its implementation through quality planning, quality control, quality assurance and quality improvement. Although quality management can be defined in various versions, but basically quality management focuses on continuous improvement to meet customer satisfaction.

\section{Hypothesis}

\section{The Effect of EWOM to Brand Awareness}

EWOM is a medium for conveying various information and having conversations with many people via the web or blog. Consumer opinion about a product through internet media is not always positive, there are also many negative opinions that develop. EWOM can affect consumer brand awareness. If a positive development EWO can create good brand awareness of a product. Conversely, a negative EWOM will make brand awareness worse. The research conducted by Raharja \& Dewakanya (2020) and Syahrivar \& Ichlas (2018) shows that EWOM has a significant effect on consumer purchasing decisions. Then the hypothesis can be formed as follows: $\mathbf{H}_{1}$ : EWOM has significant effect on brand awareness.

\section{The Effect of Price Perception to Brand Awareness}

Price is also the only revenue-generating element of the marketing mix, all other elements represent only price. Price is also one of the most flexible elements of the marketing mix. The price level is an important factor in increasing consumer knowledge and the ability of consumers to recognize and remember these products. The research conducted by Khurram, Qadeer, \& Sheeraz (2018) and Nurcahya (2014) shows that price perception has a significant effect on consumer purchasing decisions. Then the hypothesis can be formed as follows: $\mathbf{H}_{2}$ : Price perception has significant effect on brand awareness.

\section{The Effect of Product Quality to Brand Awareness}

A quality product is a product that has the ability to meet the needs and desires of consumers so as to increase consumer memory of the product brand. The quality of a product is one of the important considerations of consumers in prioritizing one brand as the main alternative when making a purchase. Good product quality makes it easier for consumers to recognize and remember a product brand, but if the quality of the product is poor, it is possible that consumers will not want to know and remember it. The research conducted by Hamid, Rasool, Kiyani, \& Ali (2012) and Hanaysha, Hilman, \& AbdulGhani (2014) shows that product quality has a significant effect on consumer purchasing decisions. Then the hypothesis can be formed as follows: $\mathbf{H}_{3}$ : Product quality has significant effect on brand awareness.

\section{The Effect of EWOM to Purchase Decision}

Electronic word-of-mouth (EWOM) communication can affect several kinds of conditions, namely awareness, expectations, perceptions, attitudes, desire to do, and consumer purchasing decision behavior. When shopping online, consumers face many choices, on the other hand, consumers have little direct information about the product because consumers cannot touch or feel the product. To overcome this weakness, an online customer review was created that provides relevant information to consumers. The research conducted by Hardjono, Riyadi, \& Aris (2020) and Poturak \& Turkyilmaz (2018) shows that EWOM has a significant effect on consumer purchasing decisions. Then the hypothesis can be formed as follows: $\mathbf{H}_{4}$ : EWOM has significant effect on purchase decision.

\section{The Effect of Price Perception on Purchase Decision}

Price is something that consumers pay attention when making a decision to purchase. Some consumers even identify the price as a value and key factors for the purchase decision. Consumers are attracted to high quality products at affordable prices. Consumers assume that a product with an expensive price means that it has good quality, but if the price is low it has poor quality. The research conducted by Albari \& Safitri (2018) and Rommy, Moh, \& Nur (2018) shows that price perception has a significant 
effect on consumer purchasing decisions. Then the hypothesis can be formed as follows: $\mathbf{H}_{5}$ : Price perception has significant effect on purchase decision.

\section{The Effect of Product Quality on Purchase Decision}

At the stage of developing a product, the producer must determine the quality that will support the product's position in the market. Quality can be defined as providing greater superiority in a product as a comparison with competing alternatives from a market point of view. Consumer evaluation of product quality will be able to help them to consider which product to buy. If the product quality offered getting better, it will be easier for consumers to make a decision buy the product. The research conducted by Amron (2018) and Foster \& Johansyah (2019) shows that product quality has a significant effect on consumer purchasing decisions. Then the hypothesis can be formed as follows: $\mathbf{H}_{6}$ : Product quality has significant effect on purchase decision.

\section{The Effect of Brand Awareness on Purchase Decision}

If a brand is in the memory of consumers, so the brand will be considered for selection in their purchasing decisions. Besides, customers will always consider top brands of mind before deciding to buy a product, despite the fact if not all the brands that occupy top of mind are also liked by customers. Customers are prefer to buy familiar brands because its something known and they think if familiar brands can be relied upon and accountable for quality. The research conducted by Ansari, Ansari, Ghori, \& Kazi (2019) and Noorlitaria A., Pangestu, Fitriansyah, Surapati, \& Mahsyar (2020) shows that brand awareness has a significant effect on consumer purchasing decisions. Then the hypothesis can be formed as follows: $\mathbf{H}_{7}$ : Brand Awareness has significant effect on purchase decision.

\section{METHODS}

This type of research is quantitative by obtaining data through distributing personal questionnaires whose results are packaged in numbers and the analysis uses statistics so that the results are in accordance with concrete scientific principles that are empirically, objective, measurable, rational, and systematic. The independent variables in this research are electronic word-of-mouth, price perception, and product quality. Electronic word-of-mouth (EWOM) is the Web-based interpersonal communication between strangers to deliver the information about a product, service, or company without commercial purpose (Fan, Miao, Fang, \& Lin, 2013). Price perception is all information relating to prices which is comprehensively understood by consumers in providing meaning in their minds (Putra et al., 2020). Product quality is the overall characteristics of product which affect the ability to meet stated and implied needs (Kotler \& Keller, 2016). Brand awareness is an intervening variable and purchase decision as the dependent variable. Brand awareness shows the ability of a prospective buyer to recognize or recall that a brand is part of a certain product category (Akkucuk \& Esmaeili, 2016). Purchase decision is attitudes or actions taken by consumers in determining the choice of several alternative products (Hasan, Wahid, \& Basalamah, 2016). The sampling technique in this study was purposive sampling with 170 respondents who were students of Dian Nuswantoro University. The data analysis tool used was the structural equation model with IBM SPSS AMOS 24. 




Figure 2. Path Analysis

Information:

$\mathrm{X} 1=$ Electronic Word-of-mouth

$\mathrm{X} 2=$ Price Perception

X3 = Product Quality

$\mathrm{Y}=$ Purchasing Decision

FINDING

An explanation of the characteristics of respondents based on gender can be seen in the following table:

Table 2. Respondents Identity Based on Gender

\begin{tabular}{cccc}
\hline No & Gender & Frequency & Percentage \\
\hline 1 & Male & 77 & $45.29 \%$ \\
2 & Female & 93 & $54.71 \%$ \\
& Total & 170 & $100.00 \%$ \\
\hline
\end{tabular}

Source: Primary data processed, 2020.

Based on Table 2 it can be seen that most of the Pegipegi application customers are women, there are 93 respondents $(54.71 \%)$, while male respondents are 77 respondents $(45.29 \%)$.

An explanation of the characteristics of respondents based on age can be seen in the following table:

Table 3. Respondents Identity Based on Age

\begin{tabular}{cccc}
\hline No & Age (years) & Frequency & Percentage \\
\hline 1 & $18-19$ & 57 & $33.53 \%$ \\
2 & $20-21$ & 75 & $44.12 \%$ \\
3 & $22-23$ & 38 & $22.35 \%$ \\
& Total & 170 & $100.00 \%$ \\
\hline
\end{tabular}

Source: Primary data processed, 2020.

Based on Table 3, it can be seen that most of the Pegipegi application customers are 20-21 years old with a total of 75 respondents, then the second largest respondents is the 18-19 year age range, and the least Pegipegi application customers are the 22-23 year old range.

An explanation of the characteristics of respondents based on semester can be seen in the following table:

Table 4. Respondents Identity Based on Semester

JMER, 2020, 01(2), 132-144 


\begin{tabular}{cccc}
\hline No & Semester & Frequency & Percentage \\
\hline 1 & 1 & 13 & $7.65 \%$ \\
2 & 3 & 26 & $15.29 \%$ \\
3 & 5 & 47 & $27.65 \%$ \\
4 & 7 & 74 & $43.53 \%$ \\
5 & 9 & 10 & $5.88 \%$ \\
& Total & 170 & $100.00 \%$ \\
\hline
\end{tabular}

Source: Primary data processed, 2020.

Based on Table 4, it can be seen that most of the Pegipegi application customers at Dian Nuswantoro University Semarang are 74 respondents by semester 7 students, 47 respondents with semester 5, 26 respondents with semester 3,13 respondents with first semester, and 10 respondents with semester 9 .

An explanation of the characteristics of respondents based on faculty can be seen in the following table:

Table 5. Respondents Identity Based on Faculty

\begin{tabular}{|c|c|c|c|}
\hline No & Faculty & Frequency & Percentage \\
\hline 1 & Computer Science & 56 & $32.94 \%$ \\
\hline 2 & Economics and Business & 77 & $45.29 \%$ \\
\hline 3 & Cultural Science & 10 & $5.88 \%$ \\
\hline 4 & Engineering & 13 & $7.65 \%$ \\
\hline 5 & Health & 14 & $8.24 \%$ \\
\hline & Total & 170 & $100.00 \%$ \\
\hline
\end{tabular}

Source: Primary data processed, 2020.

Based on Table 5, it can be seen that most of the Pegipegi application customers at Dian Nuswantoro University Semarang from Faculty of Economics and Business with a total of 77 respondents, 56 respondents from Faculty of Computer Science, 14 respondents from Health Faculty, 10 respondents from Faculty of Humanities, and 13 respondents from Engineering faculty. The Structural Equation Modeling (SEM) is used to determine the structural relationship among variables studied. The structural relationship between the suitability test variables is the Goodness of fit index. The results of the Structural Equation Modeling (SEM) analysis in this research can be seen in Figure 3 as follows:

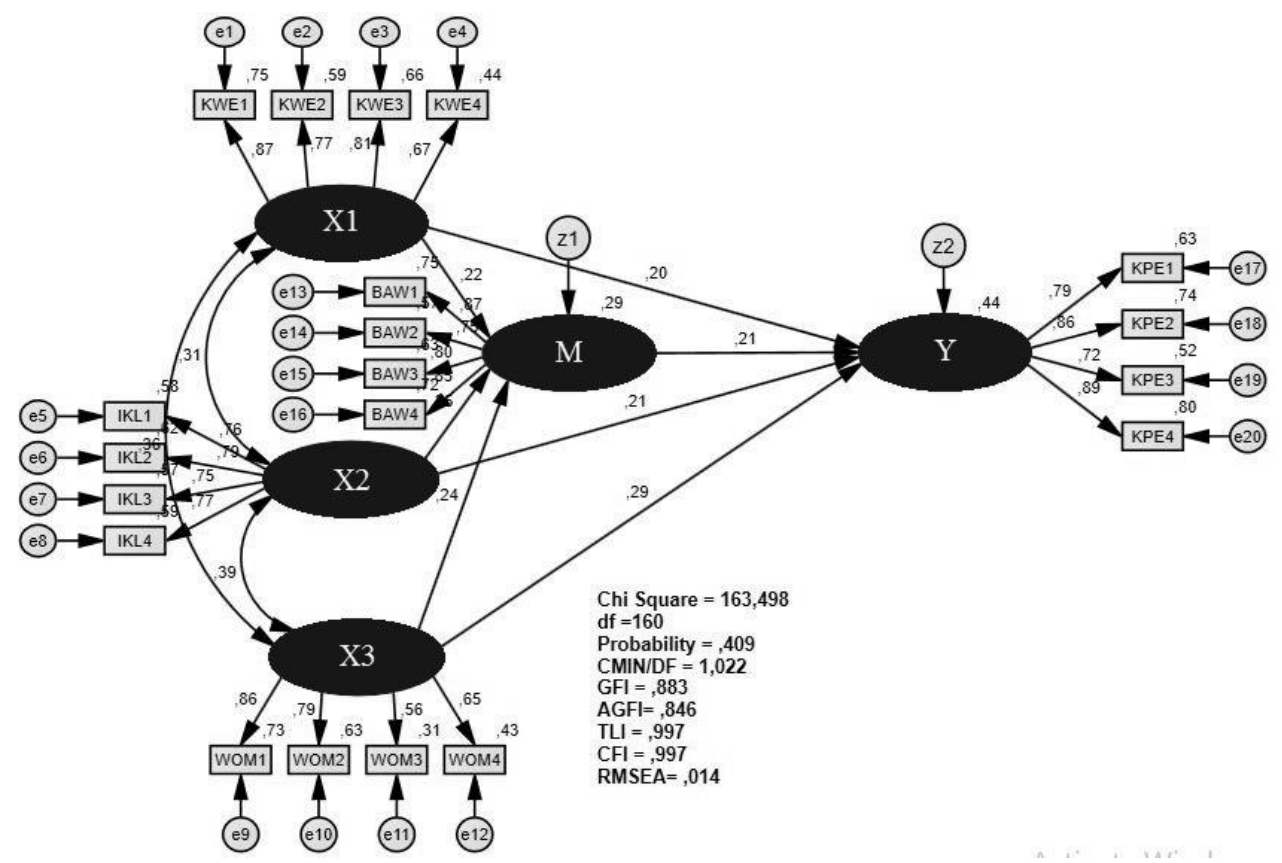

Figure 3 . The results of data processing by SEM

In the first equation shows the coefficient of EWOM influence on brand awareness is 0.22 . The coefficient of the effect of price perception on brand awareness is 0.26 . The coefficient of the influence of product quality on brand awareness is 0.24 . The second equation shows the coefficient of EWOM influence on purchasing decisions is 0.20 . The coefficient of the effect of price perception on purchasing 
decisions is 0.21 . The coefficient of the influence of product quality on purchasing decisions is 0.29 . The coefficient of influence of brand awareness on purchasing decisions is 0.29 . Based on the coefficient value obtained, the following equation can be made:

$\mathrm{M} \quad=0.22 \mathrm{X} 1+0.26 \mathrm{X} 2+0.24 \mathrm{X} 3$

$\mathrm{Y}=0.20 \mathrm{X} 1+0.21 \mathrm{X} 2+0.29 \mathrm{X} 3+0.21 \mathrm{M}$

Table 6. Structural Equation Model Fit Test

\begin{tabular}{clccc}
\hline No. & Goodness of Fit Index & Cut-off Value & Analysis Result & Meaning \\
\hline 1 & Chi-square & $<($ df:170, $: 0.05)$ & 163.498 & Fit \\
2 & CMIN/DF & $<2.00$ & 1.022 & Fit \\
3 & Probability & $>0.05$ & 0.409 & Fit \\
4 & GFI & $>0.90$ & 0.883 & Moderate fit \\
5 & AGFI & $>0.90$ & 0.846 & Moderate fit \\
6 & TLI & $>0.90$ & 0.997 & Fit \\
7 & CFI & $>0.95$ & 0.997 & Fit \\
8 & RMSEA & $<0.08$ & 0.014 & Fit \\
\hline
\end{tabular}

Source: Primary data processed, 2020.

Based on the table above, the results of the data processing analysis show that all the requirements needed have met the goodness of fit criteria. Then the chi square value is 163.498 with a probability of $0.409>0.05$, CMIN/DF value is $1.022<2.00$, GFI value is $0.883>0.90$, AGFI value is $0.846>0.90$, TLI value is $0.997>0,90$, CFI value of $0.997>0.95$ and RMSEA of $0.014<0.08$ indicate that the suitability test of this model produces a good acceptance. Therefore, it can be concluded that the structure equation model in this study can be applied.

Table 7. Validity and Reliability Test Results

\begin{tabular}{lcc}
\hline \multicolumn{1}{c}{ Variable } & Construct Reliability & Variance Extracted \\
\hline EWOM & 0.863 & 0.611 \\
Price Perception & 0.847 & 0.581 \\
Product Quality & 0.811 & 0.524 \\
Brand Awareness & 0.877 & 0.667 \\
Purchasing Decision & 0.890 & 0.671 \\
\hline
\end{tabular}

Source: Primary data processed, 2020.

The limit value used to assess an accepted level of reliability is 0.70 . Meanwhile, the calculation results show that the reliability value of the EWOM variable indicator is 0.863 , the price perception variable is 0.847 , the product quality variable is 0.811 , the brand awareness variable is 0.877 and the purchasing decision variable is 0.890 . These results indicate that the indicators used are declared reliable to measure each research variable. Meanwhile, the recommended extracted variance value is 0.50 . Based on the calculation results show that the variance extracted EWOM is 0.611 , the price perception variable is 0.581 , the product quality variable is 0.524 , the brand awareness variable is 0.667 and the purchasing decision variable is 0.671 . So it can be concluded that the indicators used are declared valid for measuring each research variable.

Table 8. Hypothesis Test Results

\begin{tabular}{|c|c|c|c|c|c|c|}
\hline & & & Estimation & S.E. & C.R. & $\mathrm{P}$ \\
\hline Brand Awarenes & $<---$ & EWOM & .295 & .139 & 2.127 & .033 \\
\hline Brand Awarenes & $<---$ & Price Perception & .260 & .115 & 2.270 & .023 \\
\hline Brand Awarenes & $<---$ & Product Quality & .389 & .185 & 2.108 & .035 \\
\hline Purchasing Decision & $<---$ & EWOM & .275 & .137 & 2.002 & .045 \\
\hline Purchasing Decision & $<---$ & Persepsi Harga & .234 & .112 & 2.095 & .036 \\
\hline Purchasing Decision & $<---$ & Product Quality & .500 & .184 & 2.716 & .007 \\
\hline Purchasing Decision & $<---$ & Brand_Awarenes & .223 & .107 & 2.092 & .036 \\
\hline
\end{tabular}

Based on the results of hypothesis testing, it can be proven as follows: 
1. The results of the effect of EWOM on brand awareness can be seen from the cr value of 2.123, which is greater $(>) 2.00$ and prob. 0.033 is smaller $(<) 0.05$, so this result proves the hypothesis that EWOM has an effect on brand awareness.

2. The results of the effect of price perception on brand awareness can be seen from the cr value of 2,270 , which is greater $(>) 2.00$ and prob. 0.023 is smaller $(<) 0.05$, so this result proves the hypothesis that price perceptions affect brand awareness.

3. The results of the effect of product quality on brand awareness can be seen from the cr value of 2.108 , greater $(>) 2.00$ and prob. 0.035 is smaller $(<) 0.05$, so this result proves the hypothesis that product quality has an effect on brand awareness.

4. The results of the effect of EWOM on purchasing decisions can be seen from the cr value of 2.002, which is greater $(>) 2.00$ and the probability of 0.045 is smaller $(<) 0.05$, so this result proves the hypothesis that EWOM has an effect on purchasing decisions.

5. The results of the effect of price perceptions on purchasing decisions can be seen from the cr value of 2.095 which is greater $(>) 2.00$ and the probability of 0.036 is smaller $(<) 0.05$, so these results prove the hypothesis that price perceptions affect purchasing decisions.

6. The results of the effect of product quality on purchasing decisions can be seen from the cr value of 2.716 , which is greater (>) 2.00 and the probability of 0.007 is smaller $(<) 0.05$, so these results prove the hypothesis that product quality affects purchasing decisions.

7. The results of the effect of brand awareness on purchasing decisions can be seen from the cr value of 2.095 which is greater $(>) 2.00$ and the probability of 0.036 is smaller $(<) 0.05$ so that the se results prove the hypothesis that brand awareness has an effect on purchasing decisions.

\section{DISCUSSION}

EWOM represents the information, interaction, and service quality of the information research and the function in marketing. EWOM has a big role in influencing brand awareness due to information and security in the Pegipegi application and the ease of operating Pegipegi travel in the quality of online services to customers. Pegipegi also pays attention to EWOM in an effort to attract customer desires to make purchasing decisions. Customers give the highest rating regarding getting Pegipegi information frequently from friends to social media and recommend it to others (score of 7.6). The highest rating given shows that the use of the Pegipegi application greatly affects customers to make purchases because they have used it. This shows that customers are familiar with the Pegipegi application because they have already used the application and get positive values such as being comfortable and easy to use with the display provided in the Pegipegi application. If customers already know and remember the brand well, it will be easier for them to make purchasing decisions without hesitation.

Customers give a high assessment of the Pegipegi application advertisement with a value of 6.92 indicating that the Pegipegi application has a strong price perception for travel products. The better the customer's perception of the price of the product offered at an affordable price, the more appropriate the price shown with the application product performance. Thus, price competitiveness compared to others will further increase brand awareness from customers. The assessment and perception of customers from one another to a certain price varies depending on their personal characteristics and customer background, thus customers do not need to compare the prices offered by other applications because Pegipegi has become a necessity at the lowest price and customers easily make purchase decisions.

Customers will also compare one product to another and will pay more attention to products that provide benefits. In this case, customers not only want to fulfill their needs, but also can satisfy their desires. Therefore, ticket booking application service providers and hotels must have a product with the best product quality to satisfy customers. Product quality is an important advantage that a company must have. The higher the ability of the application product to meet customer needs and satisfy customers, the higher the brand awareness will be. In the future, customers make a purchase decision for a brand with product advantages and recommend it to friends or relatives as new potential customers in order to have the same experience. 


\section{CONCLUSION}

Based on the research results, the following conclusions can be drawn:

1. Electronic Word-of-mouth has a positive and significant effect on purchasing decisions with a loading factor level of 0.292. If products and promotions are improved, the Electronic Word-ofmouth regarding Pegipegi will be better and Pegipegi's brand awareness will be increasingly trusted by customers. Thus customers will buy products in the Pegipegi application.

2. Price perception has a positive and significant effect on brand awareness with a loading factor level of 0.245. Based on the results of the questionnaire, the Pegipegi application satisfies customers from the price offered to the price match with the services provided. Thus, the increasing perception of cheap prices felt by customers, it will increase the Pegipegi application brand.

3. Electronic Word-of-mouth has a positive and significant effect on brand awareness with a loading factor level of 0.241 . Based on the results of the product information questionnaire and promotion, it provides effectiveness for finding Pegipegi information. Product and promotion services are very practical and very useful for finding information and purchasing through the Pegipegi application. Thus it can be concluded that if products and promotions are increased, Pegipegi's brand awareness will be more trusted by customers.

4. Product quality has a positive and significant effect on brand awareness with a loading factor level of 0.223 . Based on the results of the questionnaire, the development of product quality makes it easier for customers to find product information in the Pegipegi application. Thus, if the quality of the product is further improved, customers will be interested in finding products using the Pegipegi application.

5. Brand awareness has a positive and significant effect on purchasing decisions with a loading factor of 0.210 . Thus, the better the Pegipegi brand, the more purchasing decisions will be.

6. Perception of price has a positive and significant effect on purchasing decisions with a loading factor level of 0.208 . Thus, if the price perception is cheaper than others, it will be easier for customers to make product purchase decisions in the Pegipegi application.

7. Product quality has a positive and significant effect on purchasing decisions with a loading factor level of 0.195. Thus, product technology increases and the ease of access and information acquisition will increase the desire of customers to make purchasing decisions for Pegipegi products.

The research limitations in this research include the scope of research objects only in Dian Nuswantoro University and this research only uses quantitative analysis. The suggestions for management implication, the strategic marketing policies should be implemented immediately, especially on improving information so that it is more detailed in informing products so that customers can easily understand information and are sure. The companies should also introduce the Pegipegi application to customers by strengthening promotional and EWOM programs so that the brand is more widely known. Besides, there are suggestions for further research on more diverse objects. This is aimed at getting results that are more comprehensive and able to describe the existing competitive conditions of the industry. Future research better using more variables to measure purchasing decisions and using qualitative research methods.

\section{ACKNOWLEDGEMENT}

The author would like to thank all participants involved for helping to collect, provide various data and information until this research can be completed with consistent support.

\section{REFERENCES}

Akkucuk, U., \& Esmaeili, J. (2016). The Impact of Brands on Consumer Buying Behavior: An Empirical Study on Smartphone Buyers. International Journal of Research in Business and Social Science (2147-4478), 5(4), 1-16. https://doi.org/10.20525/ijrbs.v5i4.551

Albari, \& Safitri, I. (2018). The Influence of Product Price on Consumers' Purchasing Decisions. Review of Integrative Business and Economics Research, 7(2), 328-337.

Amron, A. (2018). Effects Of Product Quality, Price, And Brand Image On The Buying Decision Of 
City Car Product. Archives of Business Research, 6(4), 1-8. https://doi.org/10.14738/abr.64.4374 Ansari, S., Ansari, G., Ghori, M. U., \& Kazi, A. G. (2019). Impact of Brand Awareness and Social Media Content Marketing on Consumer Purchase Decision. Journal of Public Value and Administrative Insight, 2(2), 5-10. https://doi.org/10.31580/jpvai.v2i2.896

Cummins, S., Peltier, J. W., Schibrowsky, J. A., \& Nill, A. (2014). Customer Behavior in the Online Context. Journal of Research in Interactive Marketing, 8(3), 169-202. https://doi.org/10.1108/JRIM-04-2013-0019

Fahrezzy, R. S. (2018). Pengaruh Kualitas Produk dan Harga terhadap Keputusan Pembelian Konsumen Laptop Asus. Jurnal Indonesia Membangun, 17(2), 174-183.

Fan, Y.-W., Miao, Y.-F., Fang, Y.-H., \& Lin, R.-Y. (2013). Establishing the Adoption of Electronic Word-of-Mouth through Consumers' Perceived Credibility. International Business Research, 6(3), 58-65. https://doi.org/10.5539/ibr.v6n3p58

Foster, B., \& Johansyah, M. D. (2019). The Effect of Product Quality and Price on Buying Interest with Risk as Intervening Variables (Study on Lazada.com Site Users). International Journal of Innovation, Creativity and Change, 9(12), 66-78.

Gichuru, M. J., \& Limiri, E. K. (2017). Market Segmentation as a Strategy for Customer Satisfaction and Retention. International Journal of Economics, Commerce and Management, 5(12), 544-553.

Hamid, M., Rasool, S., Kiyani, A. A., \& Ali, F. (2012). Factors Affecting the Brand Recognition; An Exploratory Study. Global Journal of Management and Business Research, 12(7), 75-82.

Hanaysha, J., Hilman, H., \& Abdul-Ghani, N. H. (2014). Direct and Indirect Effects of Product Innovation and Product Quality on Brand Awareness: Empirical Evidence from Automotive Industry. International Journal of Scientific and Research Publications, 4(11), 1-7.

Hardjono, B., Riyadi, S. A., \& Aris, D. (2020). The Implication of e-WoM Communication on Customer Preference and Purchase Decision of Electronic Gadgets. JDM (Jurnal Dinamika Manajemen), 11(1), 1-11. https://doi.org/10.15294/jdm.v11i1.21113

Hasan, S., Wahid, M., \& Basalamah, M. S. (2016). Marketing Mix Effect on the Decision of Customers in the Matter in Choosing the Home Purchase Loans in PT. BNI 46 Griya BNI (Persero) Tbk Branch Makassar. International Journal of Business and Management Invention, 5(6), 20-30.

Indiani, N. L. P., Rahyuda, I. K., Yasa, N. N. K., \& Sukaatmadja, I. P. G. (2015). Perceived Risk and Trust as Major Determinants of Actual Purchase, Transcending The Influence of Intention. ASEAN Marketing Journal, 7(1), 1-13. https://doi.org/10.21002/amj.v7i1.4601

Khurram, M., Qadeer, F., \& Sheeraz, M. (2018). The Role of Brand Recall, Brand Recognition and Price Consciousness in Understanding Actual Purchase. Journal of Research in Social Sciences, 6(2), 219-241. Retrieved from https://ssrn.com/abstract=3215875

Kotler, P., \& Keller, K. L. (2016). Marketing management (15th global ed.). England: Pearson.

Latif, W. B., Islam, M. A., \& Noor, I. M. (2014). Building Brand Awareness in the Modern Marketing Environment: A Conceptual Model. IJBT, 4(1), 69-82.

Musi, S. (2017). Future Marketing, New Wave Marketers. Jurnal Komodifikasi, 5, 87-96.

Noorlitaria A., G., Pangestu, F. R., Fitriansyah, Surapati, U., \& Mahsyar, S. (2020). How Does Brand Awareness Affect Purchase Intention in Mediation By Perceived Quality And Brand Loyalty? Journal of Critical Reviews, 7(2), 103-109. https://doi.org/10.31838/jcr.07.02.20

Nurcahya, K. E. (2014). The Impact of Perceived Advertising Spending and Price Promotion on Brand Equity: A Case of ABC Brand. IBuss Management, 2(2), 133-144.

Opusunju, M. I., \& Ojeleye, Y. C. (2017). Current Price and It Effects on Consumer Purchase Decision in Ikot Ekpene Main Market, Akwa Ibom State. International Journal of Economics and SocioLegal Sciences, 2(6), 1-13.

Parmana, P., Fahmi, I., \& Nurrohmat, D. R. (2019). The Influence of Marketing Mix Factors in Purchasing Decision for Wooden Furniture Case of Furnimart Bogor. Indonesian Journal of Business and Entrepreneurship (IJBE), 5(1), 54-64. https://doi.org/10.17358/ijbe.5.1.54

Poturak, M., \& Turkyilmaz, M. (2018). The Impact of EWOM in Social Media on Consumer Purchase Decisions: A Comparative Study between Romanian and Bosnian Consumers. Management and Economic Review, 3(2), 138-160. https://doi.org/10.24818/mer/2018.12-02

Putra, F. I. F. S., Budiantoro, R. A., Luxfiati, B. A., \& Widawati, M. W. (2020). Consumer Satisfaction Behavior Whom Consumer Satisfaction Behavior Whom Purchase Chinese Smartphone In 
Soloraya. Journal of Applied Management, 18(3), 588-596. https://doi.org/10.21776/ub.jam.2020.018.03.19

Raharja, S. J., \& Dewakanya, A. C. (2020). mpact of Electronic Word -of- Mouth on Brand Awareness in the Video Game Sector: A Study on Digital Happiness. International Journal of Trade and Global Markets, 13(1), 21-30. https://doi.org/10.1504/ijtgm.2020.10021566

Rommy, A. S. N., Moh, N. B. H. H., \& Nur, A. R. Y. N. (2018). Effect of Brand Image and Price Perception on Purchase Decision. IOSR Journal of Business and Management (IOSR-JBM), 20(8), 76-81. https://doi.org/10.9790/487X-2008027681

Sitanggang, J. M., Sinulingga, S., \& Fachruddin, K. A. (2019). Analysis of the Effect of Product Quality on Customer Satisfaction and Customer Loyalty of Indihome ATPT Telkom: Regional 1 Sumatera, Medan, North Sumatra, Indonesia. American International Journal of Business Management, 2(3), 26-37.

Sulthana, A., \& Vasantha, S. (2019). Influence of Electronic Word-of-mouth EWOM on Purchase Intention. International Journal of Scientific \& Technology Research, 8(10), 1-5.

Syahrivar, J., \& Ichlas, A. M. (2018). The Impact of Electronic Word-of-mouth (E-WoM) on Brand Equity of Imported Shoes: Does a Good Online Brand Equity Result in High Customers' Involvements in Purchasing Decisions? The Asian Journal of Technology Management, 11(1), 5769.

Trinanda, O., \& Sari, A. Y. (2019). Selfie Tourism dan Electronic Word-of-mouth sebagai Anteseden Re-Visit Intention. Jurnal Benefita, 4(3), 426-535.

Vijai, C., \& Anitha, P. (2020). The Importance Of Green Marketing. International Journal of Future Generation Communication and Networking, 13(3), 4137-4142.

Wijaya, C. V. (2017). Pengaruh Harga, Kualitas Pelayanan dan Kualitas Produk terhadap Kepuasan Konsumen Depot Madiun Masakan Khas Bu Rudy. AGORA, 5(1), 1-8.

Yasmin, A., \& Islam, S. T. (2019). Market Segmentation as a Strategy for Customer Satisfaction of Standard Chartered Bank. International Journal of Multidisciplinary Research and Development, 6(10), 106-111. 